Board of Governors of the Federal Reserve System

International Finance Discussion Papers

Number 967

March 2009

\title{
Biofuels Impact on Crop and Food Prices: Using an Interactive Spreadsheet
}

Scott Baier, Mark Clements, Charles Griffiths, and Jane Ihrig

NOTE: International Finance Discussion Papers are preliminary materials circulated to stimulate discussion and critical comment. References in publications to International Finance Discussion Papers (other than an acknowledgment that the writer has had access to unpublished material) should be cleared with the author or authors. Recent IFDPs are available on the Web at ww.federalreserve.gov/pubs/ifdp/. This paper can be downloaded without charge from Social Science Research Network electronic library at http://www.sssrn.com. 


\title{
Biofuels Impact on Crop and Food Prices: Using an Interactive Spreadsheet
}

\author{
Scott Baier, Mark Clements, Charles Griffiths, and Jane Ihrig*
}

Abstract: This paper examines the effect that biofuels production has had on commodity and global food prices. The innovative contribution of this paper is the interactive spreadsheet that allows the reader to choose the assumptions behind the estimates. By allowing the reader to choose the country, time period, supply and demand elasticities, and the size of indirect effects we explicitly illustrate the sensitivity of the estimated effect of biofuels production on prices. Our best estimates suggest that the increase in biofuels production over the past two years has had a sizeable impact on corn, sugar, barley and soybean prices, but a much smaller impact on global food prices.

Over the past two years (ending June 2008), we estimate that the increase in worldwide biofuels production pushed up corn, soybean and sugar prices by 27,21 and 12 percentage points respectively. The countries that account for most of the upward pressure on these prices are the United States and Brazil. Our best estimates suggest that the increase in U.S. biofuels production (ethanol and biodiesel) pushed up corn prices by more than 22 percentage points and soybean prices (soybeans and soybean oil) by more than 15 percentage points, while the increase in EU biofuels production pushed corn and soybean prices up around 3 percentage points. Brazil's increase in sugar-based ethanol production accounts for the entire rise in the price of sugar.

Although biofuels had a noticeable impact on individual crop prices, they had a much smaller impact on global food prices. Our best estimate suggests that the increase in worldwide biofuels production over the past two years accounts for just over 12 percent of the rise in the IMF's food price index. The increase in U.S. biofuels production accounts for roughly 60 percent of this effect, while Brazil accounts for 14 percent and the EU accounts for 15 percent. The key takeaway point is that nearly 90 percent of the rise in global food prices comes from factors other than biofuels.

JEL Classifications: E31, Q42, Q11

Keywords: Biofuels, Ethanol, Commodity Prices, Food Prices

\footnotetext{
* Author Notes: Scott Baier is an Associate Professor at the John E. Walter Department of Economics, Clemson University and visiting researcher at the Federal Reserve Bank of Atlanta; he can be reached at sbaier@clemson.edu. Charles Griffiths is an economist at the Environmental Protection Agency and can be reached at griffiths.charles@epa.gov. Mark Clements and Jane Ihrig are staff members at the Board of Governors of the Federal Reserve System and can be reached at mark.w.clements@frb.gov and Jane.Ihrig@ frb.gov. The views expressed in this paper are solely the responsibility of the authors and should not be interpreted as reflecting the views of the Environmental Protection Agency, the Board of Governors of the Federal Reserve System or of any other person associated with the Federal Reserve System.
} 


\section{Introduction}

Early 2008 saw agricultural commodity prices rise at rates that have not been witnessed in nearly 40 years. When considering the cause of this rise, one can mention the standard list of factors including growing demand from better diets as countries become wealthier, reduced yields from adverse weather shocks, and increased production costs from energy and other sources (Glauber, 2008a). However, a new factor has been attracting a lot of attention: the increased production of biofuels. Since 2005, worldwide ethanol production has nearly doubled and biodiesel production has increased nearly three-fold. The United States has boosted use of corn and soybean oil for its biofuels production, while the EU has increased use of wheat, barley, and soybeans for biofuels production, and Brazil has continued to ramp up sugar-based ethanol production.

In the United States, as shown in Figure 1, the increase in corn prices is coincident with the increase in corn-based ethanol production. Similarly, in Figure 2, soybean prices increased in tandem with U.S. biodiesel production. Some use these correlations in the data to suggest that biofuels production is responsible for the bulk of the rise in agricultural and global food prices.

This paper, using an interactive spreadsheet ${ }^{1}$, allows the reader to estimate the impact of biofuels production on food prices. The spreadsheet allows the reader to customize the analysis by (1) country or area of interest, (2) a one-year or two-year analysis, (3) assumptions about demand and supply elasticities, and (4) the size of indirect effects. When choosing each option, the spreadsheet recalculates an estimate of the impact of increases in biofuels production on individual crop prices (corn, sugar, wheat, barley, soybeans and rapeseed oil), as well as beef and global food prices. ${ }^{2}$ As shown in the analysis, the estimated effect of increased biofuels production is sensitive to the options chosen.

As illustrated by the four choices we give the reader in the analysis, estimating biofuels' effect on food prices is challenging because of the number of assumptions that must be made along the way. In the text of the paper we review what we consider to be the best-guess estimate for elasticities and the size of indirect effects and report these results. We find that the increase in biofuels production, worldwide or for the individual countries in our analysis, is a noticeable factor pushing up the prices of some agricultural crop prices, but is only a small factor pushing up global food prices.

In the United States, much attention has been focused on the stringent U.S. biofuels mandate. Our best-guess estimate is that the increase in U.S. biofuels production (ethanol and biodiesel) over the past two years ending in June 2008 pushed up corn prices by more than 22 percentage points, accounting for nearly 14 percent of the rise in corn prices. ${ }^{3}$ The increase in U.S. biofuels

\footnotetext{
${ }^{1}$ The spreadsheet can be downloaded from the Federal Reserve Board's International Finance Discussion Papers at http://www.federalreserve.gov/pubs/ifdp/2009/967/default.htm.

${ }^{2}$ Global food prices as measured by the International Monetary Fund's (IMF) food price index in its Primary Commodities Price data release.

${ }^{3}$ Clearly the size of the impact will depend on the time period reported. We choose this two-year window because biodiesel production had increased dramatically; for example ethanol production in the United States had nearly doubled and the fraction of U.S. corn used for domestic production was nearly one-third. The ending date matters as
} 
production also pushed up soybean prices (soybeans and soybean oil) by more than 15 percentage points, accounting for nearly 10 percent of the rise in soybean prices.

In addition, our analysis suggests that the EU and Brazil's increased biofuels production had sizeable impacts on crop prices. Over the past two years ending in June 2008 we find that the increase in EU biofuels production has pushed corn and soybean prices up around 3 percentage points, accounting for roughly 2 percent of the increase in the price of these crops. Also, the increase in EU biofuel production pushed barley prices up 4 percentage points, accounting for around 3 percent of the increase in the price of barley. In Brazil, the increase in sugar-based ethanol production has pushed up sugar prices 12 percentage points. Over this same time period, the increase in worldwide biofuels production has pushed up corn and soybean prices by 27 and 21 percentage points respectively. That means the increase in worldwide biofuels production accounts for almost 17 percent of the rise in corn prices and 14 percent of the rise in soybean prices.

Although biofuels had a noticeable impact on individual crop prices, they had a much smaller impact on global food prices. Our best-guess estimate is that the increase in worldwide biofuels production for the two years ending in June accounts for just over 12 percent of the rise in the IMF's food price index. The increase in U.S. biofuels production accounts for roughly 60 percent of this effect, while Brazil accounts for 14 percent and the EU accounts for 15 percent. The key take-away point, however, is that nearly 90 percent of the rise in global food prices comes from factors other than biofuels.

Finally, we compare our best-guess results to many other studies. Since the estimated effect of ethanol and total biofuels production on commodity or global food prices depends heavily on assumptions about elasticities of supply and demand, the size of indirect effects, and the time period analyzed it is important to see how our results differ from others. There are studies that find estimates consistent with what we view as our best-guess estimates. The studies whose results are closest to ours tend to be government agencies. There are a few studies, however, that find larger impacts of ethanol and biofuels production on corn or global food prices. We show that in order to get a very large ethanol impact on corn prices we must assume very inelastic demand and supply curves. Whether this realistically represents the world over the past year is a decision left up to the reader. We would argue that the last few years are not any different than other years and, therefore, we use elasticities near their historic values, which provide the estimates mentioned above. Turning to the very large estimates of biofuels production on corn and global food prices, we show that these estimates can be generated only by using unrealistic assumptions - both inelastic supply and large indirect effects. We argue these two assumptions are inconsistent and, hence, these results mislead the reader.

The remainder of the paper is as follows. Section 2 provides an overview of the biofuels market, focusing primarily on the United States production of corn-based ethanol and soybean oil-based biodiesel. We also summarize movement in various food prices. Next we turn to the estimates of biofuels' effect on food prices. We present a reduced-form equation that is the basis of the

well. June 2008 was near the peak of agricultural commodity prices and at a time when discussion of biofuels and food prices attracted the most press. It is not obvious to us whether it is more informative to ask what fraction of the 'peak' commodity prices can be explained by biofuels or the fraction at some other time period. 
estimation and we discuss each of the key assumptions that the reader can choose in estimating the effect of increased biofuels production on food prices. Section 4 highlights our best-guess impact of biofuels on crop and global food prices. Section 5 compares our findings with other studies, and in doing so highlights how sensitive the results are to each assumption. Concluding remarks are provided in section 6.

\section{Overview of Biofuels}

Biofuels are liquid, solid, or gaseous fuels derived from renewable biological sources. This includes ethanol, various other alcohol-based fuels, pyrolysis oils, gasification fuels, and biodiesel. Biofuels use was first championed by Rudolf Diesel in the late 1800s when he envisioned vegetable oil as a fuel source for his diesel engine. At the World's Fair in 1900, Diesel demonstrated his engine using peanut oil. Similarly, Henry Ford designed his model T to run on corn-based ethanol. ${ }^{4}$ In the $1920 \mathrm{~s}$, automobiles switched over to the relatively cheaper petroleum based fuels. Renewed interest in biofuels followed the rapid increase in petroleum prices in the 1970s associated with the two oil crises in 1973 and 1979 (Schmidt, 2007).

World production of biofuels is concentrated in ethanol. As shown in Figure 3, world production of ethanol was 14.1 billion gallons in 2007, while biodiesel production was about 2.5 billion gallons. The majority of world ethanol production is done by the United States (46\%) and Brazil (37\%). Production of biodiesel in 2007, on the other hand, was primarily done by the EU $(71 \%)$, with the United States producing a large part of the remainder (18\%) (FAPRI 2008).

In order to assess the impact the impact of biofuels on food prices, one needs to look at the change in biofuels production, not the stock of biofuels, over time. Not surprisingly, it turns out that the largest current producers of biofuels are the same countries that have had the fastest growth in biofuels production. The remainder of the section focuses on crops used for biofuels production by the United States and the rest of the world, and then turns to looking at other crops and food prices.

\subsection{Biofuels in the United States}

In the United States, two commodities, corn and soybean oil, account for over 90 percent of biofuels production (USDA testimony), with corn being the main feed stock for U.S. biofuels production. Recently, there has been an additional amount of imported ethanol, primarily from Brazil, Costa Rica, El Salvador, Jamaica, and Trinidad and Tobago, and a few others, although not all of that is corn-based ethanol. ${ }^{5}$ As Figure 4 illustrates, ethanol production has grown dramatically since gasoline blended with ethanol was introduced into the market in 1979. In

\footnotetext{
${ }^{4}$ For more details on the history of biofuels see the Department of Energy's "History of Biofuels" at http://web.archive.org/web/20011126062816/http://www.ott.doe.gov/biofuels/history.html and "Biofuels for Transportation" http://genomicsgtl.energy.gov/biofuels/transportation.shtml as well as the Economic Report of the President (2008).

${ }^{5}$ EIA. U.S. Imports by Country of Origin: Oxgenates - Fuel Ethanol.
} 
2000, domestic production of ethanol was 1.6 billion gallons and has grown to 6.5 billion gallons in 2007. In 2007, ethanol comprised between $4 \%$ and $5 \%$ of the total motor gasoline supply. ${ }^{6}$

The amount of the U.S. corn crop devoted to ethanol production is substantial and growing, see Figure 5. In 2001, the U.S. produced 9.5 billion bushels of corn, $7 \%$ of which (705 million bushels) went to ethanol production. In 2006, corn production had grown to 10.5 billion bushels, but $20 \%$ (2.1 billion bushels) was used for ethanol production. The corn crop devoted to ethanol in 2008 is projected to be $34 \%$ of total United States production (or about $13 \%$ of total world production). As the ethanol share increased over time, the share of corn used for other uses has either remained constant or has fallen. It is important to note that Figure 5 probably overstates the amount of corn used as livestock feed since "distiller's grains" is a byproduct of ethanol production and is used as cattle feed. Of course, when looking at ethanol's impact on corn prices one needs to look at how the increased demand of corn for ethanol production is in relation to changes in other sources of demand and changes in world supply.

Why has there been dramatic growth in corn-based ethanol over the last few years? There are several factors and we provide a list of the main drivers below:

1. The United States provides a subsidy for blending ethanol into gasoline, with the payments going to petroleum blenders in the form of a tax rebate (Elam, 2008). ${ }^{7}$

2. The U.S. government has required ethanol production as part of the Clean Air Act requiring reformulated fuel that includes an "oxygenating" agent in high smog areas.

3. The United States has a mandate on the amount of ethanol that must be blended into the fuel supply. The 2005 Energy Policy Act mandated that 4 billion gallons of renewable fuel be blended into the fuel supply in 2006. Partially because of the dramatic success in producing ethanol, the recent 2007 Energy Independence and Security Act increased this mandate, ultimately requiring 36 billion gallons of biofuels by 2022 . Only 15 billion gallons of this, however, is required to be a "renewable biofuels" like corn-ethanol, with the rest being biodiesel or advanced biofuels (see Table 1).

4. Market forces have also contributed to the rise in ethanol production. Since ethanol is a substitute for petroleum, the increase in the price of crude oil has pushed up the demand for ethanol.

A similar story can be told for biodiesel production. As mentioned above, the feedstock for biodiesel can come from a number of sources, but soybean oil is one of the lowest priced domestically produced virgin oils and is produced in the largest quantity (Ginder, 2004).

\footnotetext{
${ }^{6}$ EIA. AEO 2007, Table A11. http://www.eia.doe.gov/oiaf/aeo/excel/aeotab_11.xls Calculated as Ethanol divided by motor gasoline. This appears to be the same calculation implicit in the AEO 2007 page 81 statement "Ethanol, which made up 4 percent of the motor gasoline pool in 2006."

${ }^{7}$ This credit has been as much as 60 cents for every gallon of ethanol blended in the mid 1980s, but the 2008 Farm Bill reduced this payment to $\$ 0.46$ per gallon. There is also a $\$ 0.54$ per gallon import duty on ethanol. There is also a Federal excise tax credit for biodiesel production of 1-cent-per-gallon per percent of inclusion of biodiesel (i.e., $\$ 1.00$ per gallon of $100 \%$ biodiesel) for producers using new vegetable oil. This is also a half-cent per gallon per percent of inclusion for producers using recycled vegetable oils.
} 
Soybeans are crushed, producing a joint produce of soybean oil and soybean meal. The oil can then be fermented into methyl ester which is used to make biodiesel. Because larger scale production is relatively new, data on the amount of methyl ester produced from soybean oil is only available for the 2006/07 and 2007/08 harvest year; but the growth has been dramatic. In 2006/07, 20.5 billion pound of soybean oil was produced, with 2.8 billion pounds (14\%) for biodiesel production. In $2007 / 08$, it is projected that 20.7 billion pounds of soybean oil will have been produced, with 4.2 billion pounds ( $20 \%)$ used for biodiesel. ${ }^{8}$

\subsection{Biofuels internationally}

Precise data on the production biofuels in other countries is not as easy to obtain as United States data. This is because unlike petroleum, which is a globally traded commodity with good international trade flow data, biofuels are often domestically produced and consumed with little or no international trade. Therefore, there could be some niche biofuels markets not captured in the available data (Trostle 2008). Production of biofuels by the major biofuel producing countries is summarized in Figures 6 and 7 (FAPRI, 2008).

The United States and Brazil account for about three-fourths of world biofuels production with the United States as the largest biofuels producer in the world, producing $42 \%$ of the world's biofuels in 2007 (Coyle, 2007), with most of that in the form of corn-based ethanol. Brazil, mostly in the form of ethanol from sugarcane, accounts for approximately $32 \%$ of the world's total. In 2007, Brazil produced a little over 5 billion gallons of ethanol compared to 6.5 billion gallons of ethanol produced in the United States (Renewable Fuels Association, 2008). Presently, Brazil requires that $23 \%$ of its fuel supply to be ethanol. Brazil has also increased its biodiesel production, requiring that $2 \%$ of its diesel-fuel supply be biodiesel in 2008, with this percentage rising to $5 \%$ by 2013 (Dickerson, 2006). This mandate is expected to increase Brazilian biodiesel production for the next couple of years, likely through soybean production. ${ }^{9}$

Europe also produces a substantial portion of the world's biofuels, approximately $18 \%$ (Coyle, 2007). Unlike the U.S. and Brazil, though, the EU produces more biodiesel, primarily using rapeseed and soybeans, than ethanol. Other countries that produce noticeable amount of biofuels are China, Canada, Argentina, Indonesia and India. China and Canada both use some corn for ethanol production, but are trying to diversify the feedstock to wheat, sweet potatoes, and cassava. Biodiesel in Argentina and Indonesia is produced using a variety of feedstock including soybeans and palm oil (Coyle, 2007).

\subsection{Crop substitution and indirect effects}

The choice of which crops to use for biofuels production depends on a number of factors: what has been traditionally grown, which crops are suitable for that climate, and the technologies available for converting crops into fuel. These factors place constraints on how much and what type of biofuels can be produced. With market determined prices, an increase in demand puts upward pressure on biofuels prices. If the relative cost of producing biofuels with a given crop

\footnotetext{
${ }^{8}$ U.S. Census Bureau. Table 3a: Fats and Oils, Production, Consumption, and Stocks -2007.

${ }^{9}$ USDA Long-Term Projections, February 2008.
} 
rises, another crop may be substituted. For all crops, however, crops will only be used for biofuels production if the cost of production is less than the associated cost of using petroleum, absent any other driving factor such as government mandates.

Soybeans are most directly affected by the demand for corn-based ethanol because corn and soybeans tend to compete for land area. This is because corn and soybeans can be used in rotation, for example rotating a corn and a soybean crop every other year. In practice, other cycles including other crops are used. As the price of corn rose substantially in 2007-08, reflecting the increase in demand, the cropping pattern has changed, with more corn production relative to soybeans. This has lead to a noticeable decrease in overall soybean production and increased its price (Westcott, 2007). There is now also feedback to corn from soybeans as the soybean price has risen.

Besides soybeans, other crops compete for land area. Corn, wheat, and soybeans account for about 90 percent of acreage for the eight major field crops in the USDA projections to 2017. ${ }^{10}$ This means that as corn demand increases, wheat production and prices are also affected. Of course, there are weather and land substitution issues as wheat can be planted in more Northern regions of the United States than corn.

Crop prices also affect the price of meat and dairy products because grain is used as feed. In fact, livestock feeding is the largest single use of corn. Cattle, hogs, and poultry all use corn feed, which means that expansion in the ethanol industry will affect livestock production. Prices will adjust quickly for chicken, milk and eggs, and over a longer period of time for beef and pork. The length of time for price adjustment reflects the length of time farmers need to adjust their stock (supply) in response to the higher feed prices. One mitigating factor is that "distiller's grains" are a by-product of ethanol production and can be used as feed for ruminant animals such as beef and dairy cattle. Some research suggests that distiller's grains can comprise up to half of the cattle diet. Currently, the use of distiller grains is less suitable for hogs and poultry, which are monogastric animals (Hofstrand, 2007; Westcott, 2007).

\subsection{Food price effects}

A number of studies have estimated the impact of the rise in biofuels production on crop and food prices. Here we focus on the increase in biofuels production on crop prices such as corn and soybeans, as well as global food prices. All prices are measured by the IMF's Indices of Primary Commodity Prices. The food index excludes beverages, but includes cereals $(21.4 \%$ of the total), vegetable oils (26.5\%), meat (22.3\%), seafood $(19.0 \%)$, sugar $(5.3 \%)$, bananas and oranges $(5.4 \%)$. The cereals index consists of wheat $(46.1 \%)$, corn $(29.0 \%)$, rice $(17.8 \%)$, and barley $(7.1 \%)$. The percentages are multiplicative, so while corn is almost $30 \%$ of the cereals index and cereals are $21.4 \%$ of the food index, corn is only $(0.29 \times 0.214=) 6.2 \%$ of the overall food index. The vegetables oil index consists of all soybeans $(56.2 \%$, but broken down further into soybeans, $27.5 \%$, soybean meal, $19.0 \%$, and soybean oil, $9.7 \%$ ), rapeseed oil (7.5\%), and palm oil, sunflower oil, olive oil, fishmeal, and groundnuts. The meat index is made up of beef $(38.8 \%)$, lamb $(7.1 \%)$, swine $(30.6 \%)$, and poultry $(23.5 \%)$.

\footnotetext{
${ }^{10}$ USDA “Agricultural Baseline Projections: U.S. Crops, 2008-2017”
} 
There is no denying that the food prices have risen dramatically over the past few years. Table 2 shows the increase in prices for the IMF food index, the IMF cereals index, as well as a number of selected commodities for the 12, 24, and 36 months ending in June 2008. Food prices increased $44 \%$ over the 12 months ending June, 55\% over two years and $78 \%$ over three years. However, using a 20 year average, food price only increased $2.1 \%$ at an annual rate. The pattern is the same for cereals, but the price increases have been greater. Cereal prices rose $73 \%, 120 \%$, and $169 \%$ over the past one, two, and three years. Over the past 20 years, however, cereal prices increased at an average annual rate of only $4.7 \%$. A similar story can be told for most of the commodities listed in Table 2, with the exception of sugar. ${ }^{11}$

Note that these prices are different from the prices consumers see in the United States because the diet of American consumers is comprised of substantially more processed food. For example, the wheat in the IMF index is No.1 Hard Red Winter wheat, FOB to the Gulf of Mexico; whereas the majority of wheat in the American diet comes from processed bakery products, particularly those purchased away from the home. In general, the price for processed bakery items and particularly food purchased away from home is driven more by labor, marketing and distribution costs than it is by the raw materials. As such, the price increases listed above are much more applicable to the rise in food expenditures for individuals living in developing countries than to the rise in food expenditures for American consumers. For this paper, we will concentrate on the IMF Food Index from the IMF's Primary Commodities data for our measure of the rate of increases in global food prices.

\section{Estimating the Effect of Biofuels on Food Prices}

\subsection{Model of Direct Effects}

We begin by estimating the direct effect of increased biofuels production on each agricultural price. For ethanol, we consider the effect of increased production of ethanol on corn, sugar, barley and wheat prices. For biodiesel, we look at how the prices of soybeans and rapeseeds are affected by the increased use of these commodities in biodiesel production. We estimate the direct effect with simple supply and demand equations.

For each commodity, define market demand as follows:

$$
D=D(p)+B
$$

where $D(p)$ is world demand for the commodity NOT related to biofuels production and $B$ is the demand related to biofuels production. Totally differentiating Equation (1), we get:

$$
d D=D^{\prime}(p) d p+d B
$$

Assume that market supply is:

\footnotetext{
${ }^{11}$ To put this rate of increase of food prices in perspective, the consumer price index has increased at an average annual rate of $3.1 \%$ over the last 20 years.
} 


$$
S=S(p)
$$

Totally differentiating Equation (2) we get:

$$
d S=S^{\prime}(p) d p
$$

Equating the change in supply to the change in demand ${ }^{12}$, we get:

$$
\begin{aligned}
& S^{\prime}(p) d p=D^{\prime}(p) d p+d B \\
& S^{\prime}(p)-D^{\prime}(p) d p=d B .
\end{aligned}
$$

Dividing through by $S(p)$ gives

$$
\left[\frac{S^{\prime}(p)}{S(p)}-\frac{D^{\prime}(p)}{S(p)}\right] d p=\frac{d B}{S(p)}
$$

and since we know that $S(p)=D(p)+B$

$$
\left[\frac{S^{\prime}(p)}{S(p)}-\frac{D^{\prime}(p)}{D(p)+B}\right] d p=\frac{d B}{S(p)} .
$$

We can now multiply and divide the left-hand side of the above equation by $p$

$$
\left[\frac{\partial S}{\partial p} \frac{p}{S(p)}-\frac{\partial D(p)}{\partial p} \frac{p}{D(p)+B}\right] \frac{d p}{p}=\frac{d B}{S(p)}
$$

Where we've substituted $S^{\prime}(p)=\frac{\partial S}{\partial p}$ and $D^{\prime}(p)=\frac{\partial D(p)}{\partial p}$. Now multiply and divide the second term in brackets by $D(p)$ to obtain

$$
\left[\frac{\partial S}{\partial p} \frac{p}{S(p)}-\frac{\partial D(p)}{\partial p} \frac{p}{D(p)}\left(\frac{D(p)}{D(p)+B}\right)\right] \frac{d p}{p}=\frac{d B}{S(p)},
$$

which can be re-written as

$$
\left[\varepsilon_{S}-\varepsilon_{D}\left(\frac{D(p)}{D(p)+B}\right)\right] \frac{d p}{p}=\frac{d B / B}{S(p) / B}
$$

\footnotetext{
${ }^{12}$ We implicitly assume that inventories are constant. This assumption can matter, but it depends on the nature of the shocks. If the increase in demand is temporary in nature, then inventories can be used to smooth consumption. In this case, inventories dampen the increase in price. If the shock is permanent and it is desirable to have a stock of inventories that is proportionate to consumption, then the shock may put additional upward pressure on prices.
} 
or

$$
\% \Delta p=\frac{(B / S(p)) * \% \Delta B}{\varepsilon^{s}-\varepsilon^{d}(D(p) /(D(p)+B))}
$$

where $S(p)$ is world production. Equation (3) gives us the direct effect of the increase in biofuels production, $B$, on the individual commodity prices.

For example, if we want to measure the effect of the increased production of corn-based ethanol in the United States over the past 24 months on corn prices we can use Equation 3 with $B / S(p)$ measuring the quantity of U.S. corn used for ethanol relative to world corn production over the past 24 months and $\% \Delta B$ capturing the increase in U.S. corn use for ethanol over the past 24 months along with $\varepsilon^{d}$ and $\varepsilon^{s}$, the elasticities of demand and supply for corn, and $(D(p) /(D(p)+B))$, the non-biofuels share of world demand. Plugging these numbers into Equation (3) gives $\% \Delta p$, which is the change in the price of corn due to the increased use of corn for ethanol production over the past two years.

These estimates of direct effects, of course, are sensitive to the elasticities used in the analysis and we now turn to alternative measures that one might want to consider. ${ }^{13}$

\subsection{Elasticities}

Equation (3) relies on elasticities of both supply and demand for each agricultural commodity that is used in biofuels production. All our estimated elasticities are from the Food and Agricultural Policy Research Institute (FAPRI). ${ }^{14}$ These estimates are published in FAPRI's Elasticity Database, which are collected from the academic literature on a relatively large cross section of countries over time. Although the FAPRI data draws on the current academic literature and are the best available data on crop price elasticities across countries, these elasticity are estimates for individual countries. Therefore, simply taking the mean or median of these measures for the world supply and demand elasticities is just an approximation. With this in mind, we provide sensitivity analysis of our results. Besides choosing between mean and median values, we also include the minimum and maximum measure of the FAPRI elasticities to give an upper and lower bound for the analysis.

Table 3 presents the mean and median demand and supply elasticities for the commodities examined in this study. One thing to keep in mind is that the maximum demand elasticities in reported in Table 3 are the most negative values. We report these numbers in this manner so that if one chooses the maximum supply and demand elasticities to use in Equation (3), this will produce the smallest biofuels impact on food prices. Likewise, if one chooses the minimum

\footnotetext{
${ }^{13}$ This simple supply and demand analysis does not incorporate cross-price elasticities. To capture these effects we use the empirical correlations of prices to provide plausible upper bound estimates of the cross-price effects. We discuss this in greater detail below.

${ }^{14}$ Sugar demand elasticities from Elbobeid and Tokgoz (2008).
} 
supply and demand elasticities Equation (3) will give the largest impact of biofuels on food prices.

Generally, there is little difference between the mean and median elasticities. Our preferred elasticities are the median estimates. Since the medians are slightly lower than the means, this will, if anything, tend to push up the estimated effect of biofuels production on crop and food prices.

One might view the maximum and minimum elasticities as the long-run and short-run elasticities, respectfully. However, it is not obvious that the short-run elasticities should be used to estimate the effect of biofuel production on prices. Presumably, farmers have been aware of the subsidies and the mandated increases in ethanol production for several years and have likely taken this into account when making their production decisions. In the U.S., for example, the Energy Independence and Security Act laid out the mandated amount of ethanol production for 2008 to 2022. One aspect that may have been unanticipated would have been the increase in petroleum prices over 2007 and the first half of 2008. Since biofuels are a substitute for gasoline, the increase in petroleum prices over this period had likely increased the derived demand for all biofuels.

After choosing the elasticities one wants to use in the analysis, we plug these values in Equation (3) to get the direct effects of biofuels on commodity prices. Of course, one needs to also consider indirect effects. This is the discussion of the following subsection.

\subsection{Adding Indirect Effects}

Equation (3) is very naïve; it does not allow for indirect effects of the rise in one agricultural commodity's price on other commodity prices. But, these indirect effects can be important. Two types of indirect effects we consider are from crop substitution and the effect of agricultural prices on input costs of other food items. ${ }^{15}$ For example, as ethanol prices increase, farmers plant more corn in place of soybeans, so the rise in the price of ethanol indirectly pushes up soybean prices through a land substitution effect. In addition, corn is used as an input to beef production, so as corn prices increase there is upward pressure on beef prices because the cost of inputs has increased. We account for both of these indirect effects in this analysis.

The size of indirect effects is controversial. The obvious lower bound is no indirect effects. We denote this as " $0 \%$ indirect effects". This means that the indirect effects due to land and crop substitution are zero. The upper bound on indirect effects is a one-to-one indirect effect on prices. That is, for example, a $1 \%$ change in the price of corn due to the increase in ethanol

\footnotetext{
${ }^{15}$ Another indirect effect can be estimated from using cross-price elasticities. Although this approach sounds reasonable, these elasticities are quite small (e.g., the USDA reports -0.15 for corn to soybeans) and, therefore, the estimated indirect effects from this methodology are quite close to assuming zero indirect effects. As a result, we do not discuss this method of determining indirect effects in our analysis.
} 
production will cause a $1 \%$ increase in the price of soybeans due to indirect effects. We denote this as " $100 \%$ indirect effects".

One could simply look at the extremes of no indirect effects or $100 \%$ indirect effects; however, we think these extreme bounds are unreasonable. Our approach to calculate plausible upper bounds of the indirect effects (rather than assume 100\% indirect effects) is to attribute all the correlation between the prices of crops used in biofuels production and other food prices to the rise in the production of biofuels. That is, if a bivariate regression of the log of wheat prices on the $\log$ of corn prices yields a slope coefficient of 0.27 , then we assume that every one percent increase in corn prices pushes up wheat prices by 0.27 percent. Clearly there are other factors that cause both wheat and corn prices to simultaneously increase (e.g., changes in temperature or rainfall), or it may be that some of the co-movement of the prices can be attributed to factors that push up wheat prices first and this pushed up the price of corn. That said, to provide a plausible upper bound for the indirect effects we assume that the entire correlation between the two series is related to biofuels. We also include an option for " $50 \%$ indirect effects," which essentially assumes that the slope coefficient of these bivariate regressions is .50 .

Table 4 reports the results of bivariate regressions on monthly data on crop prices from the USDA. ${ }^{16}$ The table is to be interpreted in the following way: row 2, column 2 reports an estimate of 0.65 . This implies a one percent increase in soybean prices will push up corn prices by about $0.65 \%$ and wheat prices by about $0.25 \%$. Similarly a one percent increase in corn prices will push up soybean prices by about $0.55 \%$. We also estimate a one percent increase in wheat prices will push up barley prices by $0.74 \%$. Our estimates for the indirect effect of the increase in corn and soybean prices on beef prices are as follows: a one percent increase in corn prices will push up beef prices by $0.1 \%$, while a one percent increase in soybean prices will push up beef prices by $0.06 \%$. These indirect effects come with a 1-2 year lag, as it takes farmers this long to adjust herd size to new cost pressures. In the short run, however, it may be the case that beef prices fall when agricultural prices rise, since it may be optimal to reduce the stock in order to save on costs. Our calculations allow for the longer run effects of higher feed prices pushing up the price of beef, so we interpret the indirect effects on beef with some caveats.

In the interactive spreadsheet we allow the user to select from four indirect effects. One option is "None." With this option the total effect of the increase in biofuels production on food prices is due to direct effects (i.e., the results of Equation (3)). The other extreme is 100\% indirect effects. This will give the upper bound on the total effect of the increase in biofuels production on food prices. We do not consider either of these extremes to produce reasonable results. More reasonable indirect effect options we include are: the bivariate estimates in Table 4 and a $50 \%$ indirect effect across all crops in our analysis.

When choosing the indirect effects one must consider what option is being chosen for the elasticities. The choices of elasticities and indirect effects should be consistent. That is, minimum elasticities and $100 \%$ indirect effects are not compatible. The reason is that if we think the supply is inelastic then there will be little crop substitution and, therefore little to no impact

\footnotetext{
${ }^{16}$ Data on temperature and precipitation across countries were included in these bivariate regressions to account for some weather effects in the estimation results.
} 
on the price of other crops. Similarly, one would not want to choose maximum elasticities and $0 \%$ indirect effects.

\subsection{Time period of analysis}

The interactive spreadsheet allows the reader to consider how food prices have been impacted by the increase in biofuels over the past one or two years, with the end date always June 2008. Although the percentage point increase in agricultural prices due to the increase in biofuels production is smaller for one year as opposed to two, the contribution to the price increase in not necessarily larger. The total increase in a food price is due to many factors. If weather, or another non-biofuels factor, strongly influenced agricultural prices in a given year, then the contribution of biofuels to the price increase will be relatively small.

\section{Results}

We now turn to estimating the impact of an increase in biofuels production on food prices. There are many choices to consider when measuring the effect of increased biofuels production of food prices. Here we allow the reader to consider the following options.

- Country coverage (World, United States, European Union, Brazil, Rest of World)

- Time period (1 or 2 years)

- The size of indirect effects (none to $100 \%$ )

- Elasticities of demand and supply (elastic to inelastic)

- The Food price of interest

Individual crop price (corn, soybean, sugar, rapeseed, wheat, barley, or beef)

- Global food price (IMF food price index)

The estimated impact of the increase in biofuels production on food prices depends strongly on the options chosen. This paper includes an interactive spreadsheet that allows the reader to see how sensitive the results are to the various options. To provide an overview of the results, we report what we believe to be the most realistic and important results using what we call our best guess. Our best guess uses median elasticities and indirect effects estimated from bivariate regressions.

The following subsections highlight how U.S. biofuels production has pushed up crop prices (Section 4.1) and global food prices (Section 4.2), and how world biofuels production has pushed up global food prices (Section 4.3). There are many other individual country results in the spreadsheet. We leave it to the reader to explore the effects of increased biofuel production in other countries on crop and food prices.

\subsection{Effect of the increase in U.S. biofuels on crop prices for the two years ending in June 2008}

In the United States, two commodities, corn and soybeans account for over 90 percent of biofuels production. For this reason, the direct effect of the increase in U.S. biofuels production 
is going to show up in the prices of corn and soybeans (soybeans and soybean oil). Since corn and soybeans are substitutes and compete for land, demand for each of these commodities has an indirect effect on the price of the other. There are also indirect effects from demand for these two commodities on the prices of wheat, barley and beef. For this reason, we estimate both the direct and indirect effects of the increased production of U.S. biofuels over the past two years ending in June. Then by comparing the estimated impact of the increased biofuels production on food prices to the actual food price increase, we calculate the share of the price increase that can be attributed to the increase in U.S. biofuels production.

Table 5 provides the details of this analysis, which is a subset of the data found on the "summary tab" of the interactive spreadsheet. Beginning with the direct effects, columns 1 and 2, we estimate that the increase in U.S. biofuels production pushed up corn prices by 19 percentage points (pps), soybean prices by 5 pps, and soybean oil prices also by 5 pps. This suggests that U.S. biofuels production is having a noticeable effect on these crop prices. Since corn prices are up 162 pps over the past two years ending in June 2008, we estimate increased ethanol production accounts for about 12 percent (19/162) of the increase in corn prices.

Similarly, soybean prices (soybeans or soybean oil) are up about 156 pps over the last two years (ending in June); the increase in soy-based biodiesel production accounts for about 3 percent of the rise in soybean prices. Note that we consider how the increase in biofuels pushed up both soybeans and soybean oil. Both these, as well as soybean meal, are components of the IMF food index. Although soybean oil is the input to biodiesel, we consider the effect of increased demand for soybean oil for biodiesel to have a proportional effect on soybeans prices. Soybean meal, however, is a byproduct of soybean oil production, so if anything increased demand for soybean oil through increased biodiesel production should push down meal prices. We ignore this last indirect effect, so we may be upwardly biasing our estimates.

There are also indirect effects that we must consider, reported in columns 3 and 4 . As mentioned in section 3.3, and illustrated numerically here, there are noticeable indirect effects between corn to soybeans as wells as other crops and beef (as corn was diverted from feed stock to ethanol). Taken together, we estimate that the increase in U.S. biofuels production over the last two years ending in June pushed up corn prices by slightly more than $22 \mathrm{pps}$ accounting for 14 percent of the increase in corn prices, while soybean and soybean oil prices rose by 15 pps each, accounting for about 10 percent the price increase for each of these commodities. Therefore, we conclude, the increase in U.S. biofuels production has had a noticeable impact on these individual crop prices.

\subsection{Effect of the increase in U.S. biofuels production on global food prices for the 24 months ending in June 2008}

To calculate the effect of the increase in U.S. biofuels production on global food prices, we take the estimated effect on individual crop prices, apply the appropriate weight from the IMF food index, and sum over the individual components. ${ }^{17}$ This index puts a large weight on soybeans (7 percent of the index), wheat (10 percent) and corn (6 percent); with smaller weights for soybean

\footnotetext{
${ }^{17}$ The weights are only updated once a year. To get the appropriate weight for June of 2008, we take the 2007 weight and multiply this by the price index of the individual grain divided by the IMF food index.
} 
oil (2.6 percent) and barley (2 percent). So the effect of biofuels on these grain prices translates into a noticeable impact on this measure of global food prices. That said, we find the majority of the rise in global food prices is not accounted for by the increased production of biofuels.

Table 6, which is a subset of the data found on the "summary tab" of the interactive spreadsheet, highlights that the increase in U.S. biofuels production pushed up food prices by just over 4 pps for the 24 month period ending in June (column 5); more than half of this increase is due to indirect effects (column 3). Since global food prices rose 55 percentage points over this period, we estimate that the increase in U.S. biofuels production accounts for 7 percent of the rise in global food prices (column 6). Of this 7 percent, the largest impact comes from corn and soybeans, with just over 2 pps of the increase in global food prices coming from corn and about 1.5 pps coming from soybeans and soybean oil. Wheat also plays a visible role in pushing up global food prices. Although wheat is not used in the U.S. for biofuels production, there are indirect effects from crop substitution coming from increased demand for both corn and soybeans used in biofuels production.

\subsection{Effect of the increase in worldwide biofuels production on global food prices for the 24 months ending in June 2008}

The analysis for the world is similar to that of the United States, but it considers the impact of increased biofuels production from all countries. ${ }^{18}$ Table 7 shows that the increase in world biofuels production pushed up food prices about 7 pps (column 5) for the 24 months ending in June. This is primarily a result of corn, soybeans (including soybean oil) and sugar prices contributing about 4.7 pps. to the rise in the IMF food price index, while wheat and barley prices together contribute just over one percentage point, largely due to indirect effects. The nearly 7 pps rise in the IMF food index reflects a direct effect of the increase in biofuels production on global food prices of 3.74 pps (column 1) and an indirect effect of 3.11 (column 3). The direct effect is primarily driven from corn and soybeans being used in the increased production of biofuels, although the increase in sugar-based ethanol also had a noticeable impact. The indirect effects result from dynamics between corn, soybeans and wheat. Note that we also estimate a positive indirect effect on beef prices from corn and soybean effects, although the USDA suggests that this effect was not evident in the data through June 2008.

The nearly seven percentage point increase (column 5) in global food prices is a small share of the total increase in the IMF food price index, which rose 55 percent over the 24 month period ending in June. As a result, the increase in production of biofuels accounts for just over 12 percent of the increase in global food prices. The nearly 7 pps rise in global food prices from the increase in world biofuels production is primarily driven by the increase in U.S. biofuels production, pushing prices by about 4 pps. ${ }^{19}$ That is, roughly 60 percent of the increase in global food prices attributed to the increase in world biofuels production is explained by the ramp up in U.S. production, while the increase in European Union and Brazilian biofuels production accounts for 15 percent and 14 percent of the increase in global food prices. Other countries

\footnotetext{
${ }^{18}$ Since our analysis includes all of the countries for which there exists good biofuels production data (and this list is rather short), world biofuel production should be read as "total known" biofuel production.

${ }^{19}$ This result can be seen by selecting the individual countries in the interactive spreadsheet and using the data in columns $\mathrm{F}$ and $\mathrm{G}$ to calculate these ratios.
} 
such as Argentina, Canada, and China account for only about 5 percent of the increase in global food prices due to biofuel production.

We now turn to other studies to see how their estimates differ from our best-guess estimates and through the interactive spreadsheet we can see what types of assumptions (valid or invalid) have to be made to generate these other estimates.

\section{Comparison to Other Studies}

In recent months much has been written about the impact of biofuels on food prices. Not surprisingly, studies estimate the impact of the increase in biofuels production differently - using different countries, time periods, and food price indexes. The studies also differ in the methodologies used in the analysis. It is important to know what is being measured and how it is being measured before comparing results. Here we focus on a few studies by international organizations, private individuals, and U.S. government agencies that have attracted media attention. Our goal is to see what types of assumptions are needed to generate the results in these studies in order to evaluate if we think these estimates are realistic.

Many studies estimate ethanol's impact on corn prices. These studies, explicitly or implicitly, look at how the U.S. increase in corn-based ethanol production is affecting corn prices. Their estimated share of ethanol's effect on the increase in corn prices ranges from $20 \%$ to $60 \%$. Table 8 illustrates the range that we get by varying our assumption on supply and demand elasticities. As shown, maximum elasticities suggest that the increase in ethanol production explains only $4 \%$ of the increase in corn prices. Our best-guess estimate is that the increase in ethanol production accounts for $12 \%$ of the rise in corn prices. This is a bit less than the estimate given by Chairman Lazear of the Council of Economic Advisers (CEA) in his May 2008 Senate testimony ${ }^{20}$. He states that "the increase in U.S. corn-based ethanol production accounts for approximately 7.5 percentage points of the $37 \%$ increase in corn prices over the past twelve months [ending in March]" (Lazear, 2008). So, the CEA estimated the increase in U.S. ethanol production accounted for $20 \%$ (7.5/37) of the rise in corn prices. The difference between our estimate and the CEA's is likely attributed to the additional run-up in corn prices from March to June; over this four month period corn prices increased more than 22 percent while ethanol production did not ramp up.

The International Monetary Fund's October 2008 World Economic Outlook provides a range for the share of the rise in corn prices attributable to ethanol production in the United States of $25-45 \%$. They state this estimate holds for "a given range of plausible values for the price elasticity of demand" (IMF 2008). This fits in our elasticity range, but only for values of elasticities that are quite low. Finally, Collins, in an independent study for Kraft foods, estimated two scenarios. Under the "normal" scenario, the increase in ethanol production accounted for $30 \%$ of the rise in corn prices over the past two years; a little more than double our best estimate expressed in Table 8. In his "restricted" scenario "ethanol could account for 60 percent of the expected increase in corn prices between 2006/07 and 2008/09 when market

\footnotetext{
${ }^{20}$ Though we are looking over slightly different time periods; Lazear's comments are for corn prices over the twelve months ending in March, and we are looking at the 12 months ending in June.
} 
demand and supply are inelastic with respect to price - i.e., a period when stocks are very low, feed use is slow to respond, export demand is strong due to foreign agricultural policies, and acreage is very constrained" (Collins, 2008). If we use the minimum demand and supply elasticities and assume that there are no indirect effects, then ethanol production accounts for, at most, $45 \%$ of the increase in corn prices for the 24 month period ending June 2008 . We conclude that Collins' restricted scenario estimate is too large to be plausible, even under restrictive assumptions.

As one can see above, the estimated effect of the increase in ethanol production on corn prices depends strongly on the assumed elasticity. Has the supply of corn been more or less responsive to price movements this past year than in previous periods? Collins and the IMF's large estimates rely on an assumption that today's market conditions are not consistent with recent historical periods. We do not believe that this is the case and, in fact, the later part of 2008 has seen corn prices retrace most of the run-up from earlier in the year. This suggests that it was more standard factors, not ethanol, responsible for a share of the increase and then decrease in corn prices over this period.

Other studies estimate biofuels' impact on corn prices. This includes ethanol's direct impact on corn prices, as well as soybean and other biodiesel commodities' indirect effects on corn prices. The USDA's chief economist, Joseph Glauber, testified to the Senate in June 2008 about the U.S. biofuels effect on food prices. For the 12 months ending in April, USDA estimates that corn prices would have increased $47.5 \mathrm{pps}$ instead of $61.7 \mathrm{pps}$, implying that the increase in U.S. biofuels accounted for about 25 percent of the rise in corn prices (Glauber, 2008b). In Table 9, our best-guess estimate is that the increase in U.S. biofuels production over the past year accounted for 17 percent of the rise in corn prices over this same 12 month period. The two estimates imply that roughly 80 percent of the price increase of corn is due to factors other than increased biofuels production.

The largest estimate of biofuels impact on corn prices comes from the IMF. John Lipsky (2008) and Simon Johnson (2008) independently suggested that the increased demand for world biofuels between 2005 and 2007 accounts for 70 percent of the increase in corn prices. As shown in Table 9, the closest we can come to this estimate is if we use our minimum elasticity AND 100\% indirect effects. However, as noted before, minimum elasticities and 100\% indirect effects cannot occur at the same time since minimum elasticities imply no supply response in the short run and hence this means crop substitution is not possible. Therefore, we find that the IMF estimate is not realistic. In fact, if one looks at the data behind the IMF statement, one sees that the analysis attributes the rise in corn prices exclusively to energy or biofuels and excludes other factors. Therefore, the study is putting the effect of all other factors into these two categories, inflating the biofuels impact on corn prices in their analysis.

Finally, we turn to studies of biofuels' impact on global food prices. All studies use the IMF food index in the primary commodities index as a proxy for global food prices. The USDA's chief economist testified that "assuming no growth in biofuels production in the United States, the IMF global food commodity price index would have increased by 40.6 percent, down from the actual increase of 45.0 percent, from April 2007 to April 2008" (Glauber, 2008b). This suggests that the increase in U.S. biofuels production accounts for about 10 percent of the rise in 
global food prices over that period. This is double our best-guess estimate of roughly $5 \%$ over the 12 months ending in June 2008; however, the time period is a bit different and will make our estimate smaller than one using April 2008 as an end point.

A study that suggests a large impact of biofuels on global food prices is by the World Bank. This study finds that from 2002 to mid-2008, "most of the remaining 75 percent increase in food commodities prices was due to [world] biofuels and the related consequences of low grain stocks, large land use shifts, speculative activity and export bans" (Mitchell, 2008). The data for biofuels production that we consider reliable does not go back to 2002, but even looking over the past 2 years, as shown in Table 10, one can see that a contribution close to $75 \%$ is only possible if one assumes inelastic supply and demand combined with $100 \%$ indirect effects. As we stated before, these combined assumptions are not economically reasonable. The World Bank study, however, does not base its biofuels estimate on standard economic modeling - it calls its methodology "ad hoc." The study only quantifies three factors responsible for pushing up global food prices: energy, the dollar, and biofuels. Using data on the movement in the dollar and energy prices over the past several years, the study estimates the impact of these factors on food prices. The effect of biofuels is the residual. The study argues the impact of other factors (adverse weather, increased demand from emerging markets, etc) is appointed to the increase in biofuels production because without biofuels production these other factors would not have had an effect on global food prices. One has to decide if this "ad hoc" methodology should be used instead of standard economic analysis. In our opinion, the answer is no.

In summary, there are many studies with very different estimates of the impact of biofuels on crop and global food prices. Various assumptions are being made to get these estimates - some of which are economically reasonable and feasible, while others seem a bit unrealistic. Unfortunately, most media attention has been given to the extreme estimates without much consideration for the economic assumptions that must be made to generate these results. Once we look at the underlying assumptions, we see that these eye-popping estimates are unrealistic.

\section{Conclusion}

This paper, with its interactive spreadsheet, provides a nice foundation for analyzing the effect of biofuels production on crop and global food prices. By allowing the reader to choose the country, time period, supply and demand elasticities, and the size of indirect effects, we explicitly illustrate the sensitivity of the estimated effect of biofuels production on prices. Our best estimates suggest that the increase in biofuels production over the past two years has had a sizeable impact on corn, soybeans, wheat and barley prices, but a much smaller impact on global food prices. The small effect on food prices results from the fact that there are many components of the food index that are not affected by biofuels.

Our best estimates suggest that the United States' increase in biofuels production (ethanol and biodiesel) over the 24 months ending in June 2008 pushed up corn prices by 22 percentage points, accounting for 14 percent of the rise in corn prices, and pushed up soybean prices (soybeans and soybean oil) by 15 percentage points, accounting for about 10 percent of the rise in these prices. As a share of the total crop price increases, ethanol's contribution is small. 
However, in absolute terms, these are sizeable effects. We estimate that the increase in world biofuels production accounts for just over $12 \%$ of the rise in global food prices, with increased U.S. biofuel production accounting for roughly $60 \%$ of this total increase. Though the United States accounts for roughly 60 percent of the total increase of the IMF's food price index due to biofuels production, the increase is small, just over 7 percent. Therefore, we conclude that nearly 90 percent of the price increase in global food prices is due to factors other than biofuels production.

Our analysis also highlights that other studies, which find much larger effects of biofuels production on crop and food prices, can only be generated using unrealistic assumptions - both inelastic supply and large indirect effects. We argue that these two assumptions are inconsistent and, hence, these studies are misleading. In the end, we leave the reader with our interactive spreadsheet to determine what they believe are valid assumptions to determine their own estimate of the impact of biofuels production on food and crop prices. 


\section{References}

Abbot, P., Hurt, C., \& Tyner, W. (2008). What's Driving Food Prices. Farm Foundation Issue Report (75).

Collins, K. (2008). The Role of Biofuels and Other Factors in Increasing Farm and Food Prices: A Review of Recent Developments with a Focus on Feed Grain Markets and Market Prospects. Kraft Foods Global, Inc.

Council of Economic Advisers. (2008). Searching for Alternative Energy Solutions. In Economic Report of the President (pp. 163-185). Washington DC: Executive Office of the President.

Coyle, W. (2007). The Future of Biofuels: A Global Perspective. Amber Waves , 5 (5), 24-29.

Dickerson, M. (2006, September 19). Farmers' Hopes Sprout as Brazil Bets on Biodiesel. Los Angeles Times , pp. C-1.

Elam, T. E. (2008). Biofuels Support Costs to the U.S. Economy: The Key Role of the RFS in a Feedstock Shortage Scenario. The Coalition for Balanced Food and Fuel Policy.

Elbobeid, A., \& Tokgoz, S. (2008). Removing Distortions in the U.S. Ethanol Market: What Does it Imply for the United States and Brazil. American Journal of Agricultural Economics , 90 (4), 918-932.

FAPRI (Food and Agricultural Policy Research Institute). (2008). FAPRI 2008 U.S. and World Agricultural Outlook. Ames, Iowa: University of Missouri-Columbia

Ginder, R. (2004). Evaluating Bio-diesel as a Value-added Opportunity. Agricultural Marketing Resource Center.

Glauber, J. (2008a). Statement to the U.S. Congress Joint Economic Committee. Increasing Food Prices. Washington DC: Hearing.

Glauber, J. (2008b). Statement to the U.S. Senate Committee on Energy and Natural Resources. Full Committee Hearing to Receive Testimony on the Relationship Between U.S. Renewable Fuels Policy and Food Prices. SD-366. Washington DC: Hearing.

Hofstrand, D. (2007, March). Energy Agriculture - Corn Ethanol. Ag Decision Maker Newsletter.

International Monetary Fund. (2008). Is Inflation Back? Commodity Prices and Inflation. In World Economic Outlook October 2008 (pp. 83-128). Washington DC: International Monetary Fund.

Johnson, S. (2008, April 25). Commodity Prices: Outlook \& Risks. Washington DC: International Monetary Fund. 
Lazear, E. P. (2008). Statement to the U.S. Senate Committee on Foreign Relations. Responding to the Global Food Crisis. Washington DC: Hearing.

Lipsky, J. (2008). Commodity Prices and Global Inflation. New York: Council on Foreign Relations.

Mitchell, D. (2008). A Note on Rising Food Prices. World Bank Development Prospects Groupk, Policy Working Paper, 4682.

Renewable Fuels Association. (2008). Changing the Climate: Ethanol Industry Outlook.

Schmidt, C. W. (2007). Biodiesel: Cultivating Alternative Fuels. Environmental Health Perspectives, 115 (2), A87-A91.

Trostle, R. (2008). Clobal Agricultural Supply and Demand: Factors Contributing to the Recent Increase in Food and Commodity Prices. Washington DC: United States Department of Agriculture: Economics Research Service.

Westcott, P. (2007). Ethanol Expansion in the United States: How Will the Agricultural Sector Adjust? Washington DC: United States Department of Agriculture: Economics Research Service. 


\section{Appendix}

\section{A.1. Data Appendix}

Description of tabs in Spreadsheet:

\section{Direct Effect tab}

Pulls calculations of the direct effect from Calculations tab, conditional on country, time period and elasticities chosen.

\section{Indirect effects tab}

Matrices that contain all indirect effects and possible combinations that can be chosen. Columns B-N: Indirect effect multiplied by IMF weight and price ratio in columns Q-U. Columns AL-AX: Indirect effect multiplied by price increase in columns AE-AI. Columns X-AB: Indirect effect coefficients.

\section{By Crop tab}

Takes data in Biofuels2008 tab and splits up the data by commodity and country. Total is the total production of countries given in the FAPRI data. Shares are calculated with $1 / 3+2 / 3$ since we are looking at June data.

\section{US2008}

Contains data on U.S. crop utilization from FAPRI.

\section{Biofuels2008 tab}

FAPRI's 2008 Economic Outlook, Biofuels spreadsheet. United States use in ethanol is FAPRI data (US2008 tab), converted to calendar year with $2 / 3$ first market year $+1 / 3$ second market year (convention used by FAPRI). Converted oils back to beans using extraction ratios given by FAPRI.

\section{Production_Crop tab}

This spreadsheet calculates Equation 3 in the paper.

Column B and $\mathrm{J}$ are from the World Production tab.

Column $\mathrm{C}$ and $\mathrm{K}$ are from By Crop tab

Columns D, E, L and M from Elasticities and Calculations tabs

\section{World production}

FAPRI data converted to calendar year.

\section{IMF Food Price Index tab}

Data and simple calculations.

\section{Calculations tab}

Calculates how much biofuels pushed up each crop price then calculates how much it pushed up IMF food index (worldwide) using weight of item in index and price ratio. Then the share of the worldwide increase is divided among each country. 


\section{Elasticities tab}

FAPRI database. Except demand for sugarcane which is from the Elbobeid and Tokgoz paper mentioned in the references section.

\section{Calculations2 and Direct Effect tabs}

Internal working sheet.

\section{A.2. Assumptions}

\section{Soybeans}

Biodiesel converted to soybeans. Calculate price effect on soybeans. Assume same price increase on soybean oils (not on soy meal). So biofuels effect is on soybeans and soy oil, not soy meal.

\section{Rapeseed}

We do the calculation of pushing up rapeseed prices and then assume same price increase in rapeseed oil, which is what is in the IMF index.

\section{Sugarcane}

We do the calculation of how much sugarcane price is increased and use that for sugar items in the IMF index. 


\begin{tabular}{rrrrrrr}
\hline \multicolumn{7}{c}{ Table 1- United States 2008-2022 Biofuel Standards } \\
Billion Gallons per Year \\
Year & $\begin{array}{c}\text { Renewable } \\
\text { Biofuel }\end{array}$ & $\begin{array}{c}\text { Advanced } \\
\text { Biofuel }\end{array}$ & $\begin{array}{c}\text { Cellulosic } \\
\text { Biofuel }\end{array}$ & $\begin{array}{c}\text { Biomass } \\
\text { based } \\
\text { Diesel }\end{array}$ & $\begin{array}{c}\text { Undifferentiated } \\
\text { Advanced } \\
\text { Biofuel }\end{array}$ & $\begin{array}{c}\text { Total } \\
\text { Biofuel } \\
\text { Mandate }\end{array}$ \\
2008 & & & & & 0.10 & 11.10 \\
2009 & 10.50 & 0.60 & & 0.50 & 0.20 & 12.95 \\
2010 & 12.00 & 0.95 & 0.10 & 0.65 & 0.30 & 13.95 \\
2011 & 12.60 & 1.35 & 0.25 & 0.80 & 0.50 & 12.20 \\
2012 & 13.20 & 2.00 & 0.50 & 1.00 & 1.75 & 16.55 \\
2013 & 13.80 & 2.75 & 1.00 & & 2.00 & 18.15 \\
2014 & 14.40 & 3.75 & 1.75 & & 3.50 & 20.50 \\
2015 & 15.00 & 5.50 & 3.00 & & 3.50 & 22.25 \\
2016 & 15.00 & 7.25 & 4.25 & & 4.00 & 26.00 \\
2017 & 15.00 & 9.00 & 5.50 & & 4.50 & 28.00 \\
2018 & 15.00 & 11.00 & 7.00 & & 4.50 & 30.00 \\
2019 & 15.00 & 13.00 & 8.50 & & 4.50 & 33.00 \\
2020 & 15.00 & 15.00 & 10.50 & & 5.00 & 36.00 \\
2021 & 15.00 & 18.00 & 13.50 & & & \\
2022 & 15.00 & 21.00 & 16.00 & & & \\
\hline
\end{tabular}

Source: Renewable Fuels Association

\begin{tabular}{lccccc}
\hline \multicolumn{5}{c}{ Table 2 - Rise in Food Price - Period Ending June 2008 } \\
\hline & Weight & \multicolumn{4}{c}{ Percent Change (\%) } \\
& $(\%)$ & 12-months & 2 years & 3 years & 20 year average \\
IMF food Index & 100 & 44.4 & 55.4 & 78.3 & 2.1 \\
IMF Cereals & 22 & 73.2 & 119.7 & 169.3 & 4.7 \\
Corn & 6 & 74.5 & 162.1 & 194.3 & 4.5 \\
Wheat & 10 & 56.3 & 78.6 & 145.6 & 4.3 \\
Barley & 2 & 30.7 & 125.5 & 157.9 & 5.7 \\
Soybeans & 7 & 82.4 & 155.2 & 116.9 & 2.4 \\
Soybean Oil & 3 & 80.7 & 157.1 & 167.0 & 4.3 \\
Rapeseed Oil & 2 & 81.5 & 84.5 & 141.7 & 5.7 \\
Sugar & 5 & 19.4 & -16.7 & 24.5 & 0.8 \\
Beef & 9 & 8.8 & 15.9 & 7.6 & 0.8 \\
\hline Source: International Monetary Fund's Primary Commodities Index & \multicolumn{4}{c}{} \\
\hline
\end{tabular}




\begin{tabular}{lc|c|c|c|r|r|r|r}
\hline \multicolumn{8}{c}{ Table 3 - Mean and Median Elasticities } \\
\hline & \multicolumn{9}{c}{ Demand } & \multicolumn{4}{c}{ Supply } \\
\cline { 2 - 9 } Corn & -0.23 & -0.21 & -0.51 & -0.02 & 0.23 & 0.22 & 0.70 & 0.07 \\
Sugar & -0.12 & -0.11 & -0.29 & -0.07 & 0.14 & 0.10 & 0.60 & 0.06 \\
Wheat & -0.23 & -0.26 & -0.43 & -0.05 & 0.20 & 0.19 & 0.43 & 0.07 \\
Barley & -0.25 & -0.25 & -0.57 & -0.04 & 0.24 & 0.23 & 0.45 & 0.08 \\
Soybeans & -0.24 & -.025 & -0.40 & -0.15 & 0.33 & 0.34 & 0.45 & 0.15 \\
Rapeseed & -0.21 & -0.25 & -0.30 & -0.08 & 0.29 & 0.27 & 0.36 & 0.26 \\
\hline
\end{tabular}

Sources: FAPRI and Elbobied and Tokgoz (2008)

\begin{tabular}{ccccc}
\hline \multicolumn{5}{c}{ Table 4 - Bivariate Indirect Effects (\%) } \\
\hline Indirect Effects & Corn & Soy & Wheat & Barley \\
Corn & -- & 0.65 & 0.70 & 0.34 \\
Soy & 0.55 & -- & 0.43 & 0.36 \\
Wheat & 0.27 & 0.25 & -- & 0.16 \\
Barley & 0.25 & 1.13 & 0.74 & -- \\
Beef & 0.10 & 0.06 & -- & -- \\
\hline
\end{tabular}

Memo: column is the independent variable; row is the dependent variable.

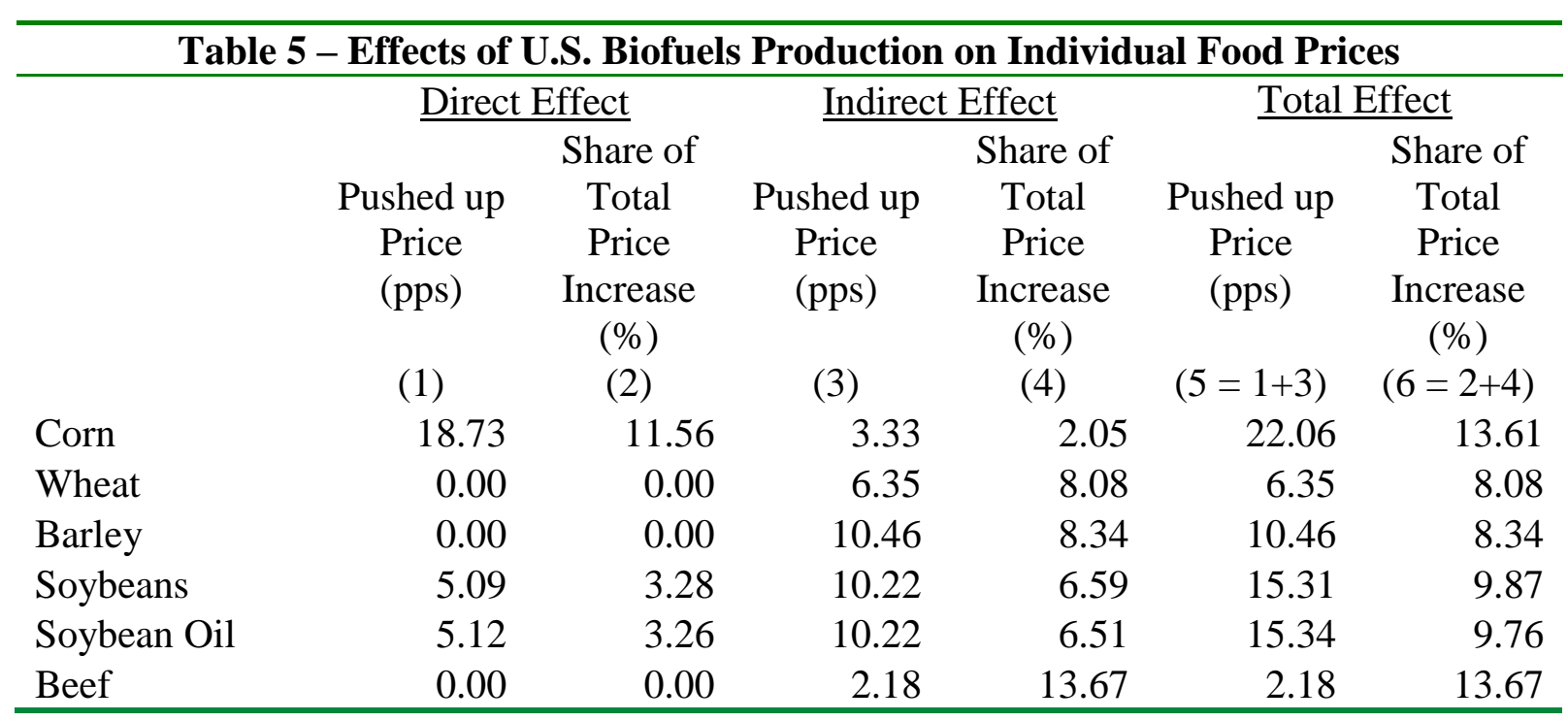




\section{Table 6 - Effects of U.S. Biofuels Production on Global Food Prices}

\begin{tabular}{lcccccr}
\hline & \multicolumn{2}{c}{ Direct Effect } \\
$\begin{array}{c}\text { Pushed up } \\
\text { Price } \\
\text { (pps) }\end{array}$ & $\begin{array}{c}\text { Share of } \\
\text { Price } \\
\text { Increase } \\
(\%)\end{array}$ & $\begin{array}{c}\text { Indirect Effect } \\
\text { Pushed up } \\
\text { Price } \\
(\mathrm{pps})\end{array}$ & $\begin{array}{c}\text { Share of } \\
\text { Price } \\
\text { Increase } \\
(\%)\end{array}$ & $\begin{array}{c}\text { Tushed up } \\
\text { Price } \\
(\mathrm{pps})\end{array}$ & $\begin{array}{c}\text { Share of } \\
\text { Price } \\
\text { Increase } \\
(\%)\end{array}$ \\
IMF Food Index & $(1)$ & $(2)$ & $(3)$ & $(4)$ & $(5=1+3)$ & $(6=2+4)$ \\
Corn & 1.56 & 2.82 & 2.45 & 4.43 & 4.02 & 7.25 \\
Wheat & 1.12 & 2.03 & 0.20 & 0.36 & 1.32 & 2.39 \\
Barley & 0.00 & 0.00 & 0.70 & 1.26 & 0.70 & 1.26 \\
Soybeans & 0.00 & 0.00 & 0.15 & 0.28 & 0.15 & 0.28 \\
Soybean Oil & 0.31 & 0.56 & 0.62 & 1.13 & 0.94 & 1.69 \\
Beef & 0.13 & 0.23 & 0.62 & 1.13 & 0.75 & 1.36 \\
\hline
\end{tabular}

Table 7 - Effects of World Biofuels Production on Global Food Prices

Direct Effect Indirect Effect

Share of

Pushed up Total

Price

(pps)

(1)
Share of

Pushed up

Price (pps)

(3)

Total

Increase

$(\%)$

(4)
3.74

1.20

0.78

0.04

0.01

0.62

0.25

0.00
6.75

2.17

1.41

0.06

0.01

1.12

0.45

0.00
Total Effect

Share of

Pushed up Total

Price Price

(pps) Increase

$(\%)$

$$
(5=1+3) \quad(6=2+4)
$$

5.62

6.85

12.36

0.76

1.62

2.93

0.00

0.78

1.41

1.59

0.92

1.66

0.45

0.25

0.46

1.24

1.31

2.36

0.69

1.24

0.94

1.69

0.18

0.33

0.18

0.33




\begin{tabular}{|c|c|c|c|}
\hline \multicolumn{4}{|c|}{$\begin{array}{c}\text { Table } 8 \text { - Share of U.S./ World Ethanol Production of Corn Price Increase* } \\
\text { Direct Effect and Various Elasticities }\end{array}$} \\
\hline & $\begin{array}{l}\text { Maximum } \\
\text { Elasticity }\end{array}$ & $\begin{array}{l}\text { Median } \\
\text { Elasticity }\end{array}$ & Minimum Elasticity \\
\hline 1 year & $4 \%$ & $12 \%$ & $51 \%$ \\
\hline 2 years & $4 \%$ & $12 \%$ & $45 \%$ \\
\hline \multicolumn{4}{|c|}{$\begin{array}{l}\text { * These estimates are the share of corn's price increase due to ethanol production; } \\
\text { only considers the direct effects; the estimates for the United States and World are } \\
\text { similar since the United States produces over } 90 \text { percent of worldwide corn-based } \\
\text { ethanol. }\end{array}$} \\
\hline \multicolumn{4}{|c|}{$\begin{array}{c}\text { Table 9 - Share of World Biofuels Production of Corn Price Increase* } \\
\text { Indirect and Direct Effect, Various Elasticities }\end{array}$} \\
\hline & $\begin{array}{l}\text { Maximum } \\
\text { Elasticity and } 0 \\
\text { indirect effects }\end{array}$ & $\begin{array}{l}\text { Median } \\
\text { Elasticity and } \\
\text { bivariate } \\
\text { indirect effects }\end{array}$ & $\begin{array}{l}\text { Minimum Elasticity and } \\
100 \% \text { indirect effects }\end{array}$ \\
\hline 1 year & $5 \%$ & $17 \%$ & $67 \%$ \\
\hline 2 years & $5 \%$ & $17 \%$ & $62 \%$ \\
\hline
\end{tabular}

* These estimates are the direct plus indirect effects of biofuels production on corn price inflation.

\begin{tabular}{lccc}
\hline \multicolumn{4}{c}{ Table 10 - Share of World Biofuels Production of Global Food Price Increase* } \\
\hline & $\begin{array}{c}\text { Median } \\
\text { Masimum } \\
\text { indicity and 0 } \\
\text { indirect effects }\end{array}$ & $\begin{array}{c}\text { Elasticity and } \\
\text { bivariate }\end{array}$ & $\begin{array}{c}\text { Minimum Elasticity and } \\
\text { indirect effects }\end{array}$ \\
$\begin{array}{lccc}100 \% \text { indirect effects } \\
\text { year }\end{array}$ & $2 \%$ & $8 \%$ & $51 \%$ \\
years & $3 \%$ & $12 \%$ & $74 \%$ \\
\hline
\end{tabular}

* These estimates are the share of food price increases due to biofuels production; these estimates consider both direct plus indirect effects on the IMF food price index. 
Figure 1 - Corn Price and US Ethanol Production, Jan. 2005 - Mar. 2008

Thousands of Barrels

Dollars per Bushel

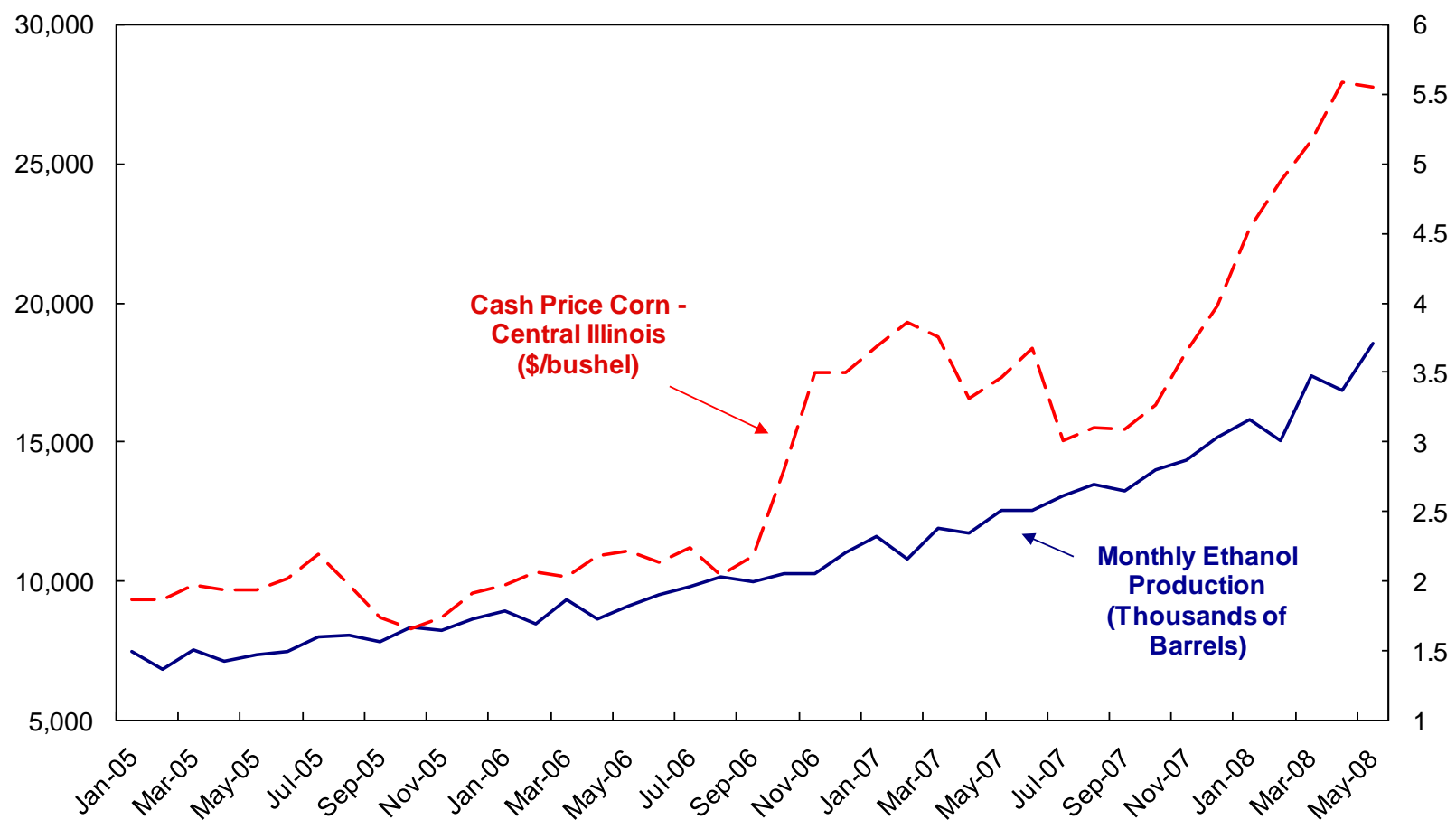

Sources: USDA and the Energy Information Association

Figure 2 - Soybean Prices and US Biodiesel Production, Jan. 2005 - Mar. 2008 Thousands of Barrels

Dollars per Bushel

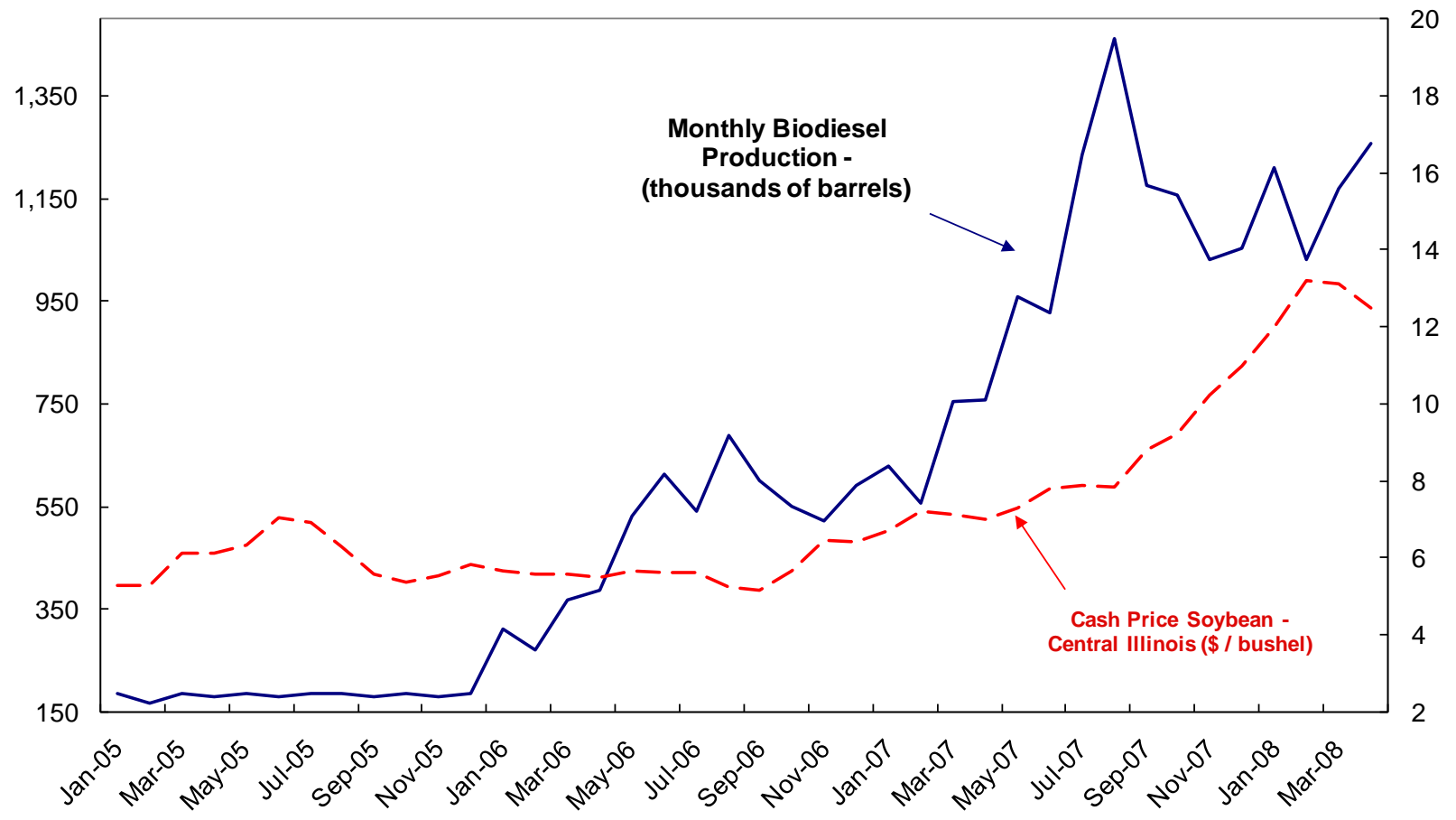

Sources: USDA and the July 2008 Monthyl Energy Review, EIA 
Figure 3 - World Ethanol and Biodiesel Production, 2007

Millions of gallons

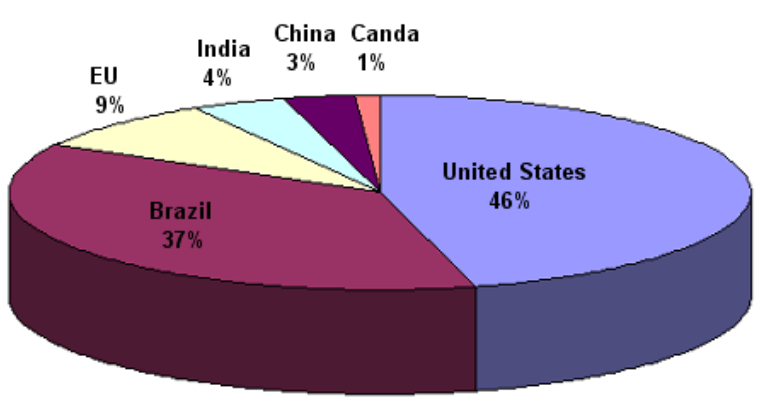

World Ethanol Production

14.1 million gallons

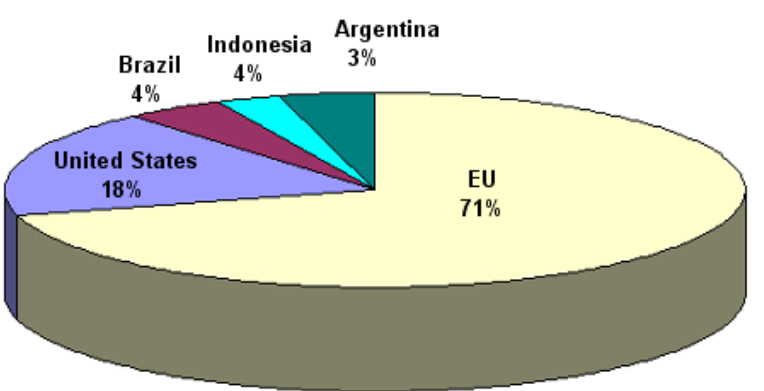

World Biodiesel Production 2.5 million gallons

Source: FAPRI 2008 U.S. and World Agricultural Outlook.

Figure 4 - Biofuel Production in the United States, 1981-2007

Millions of gallons

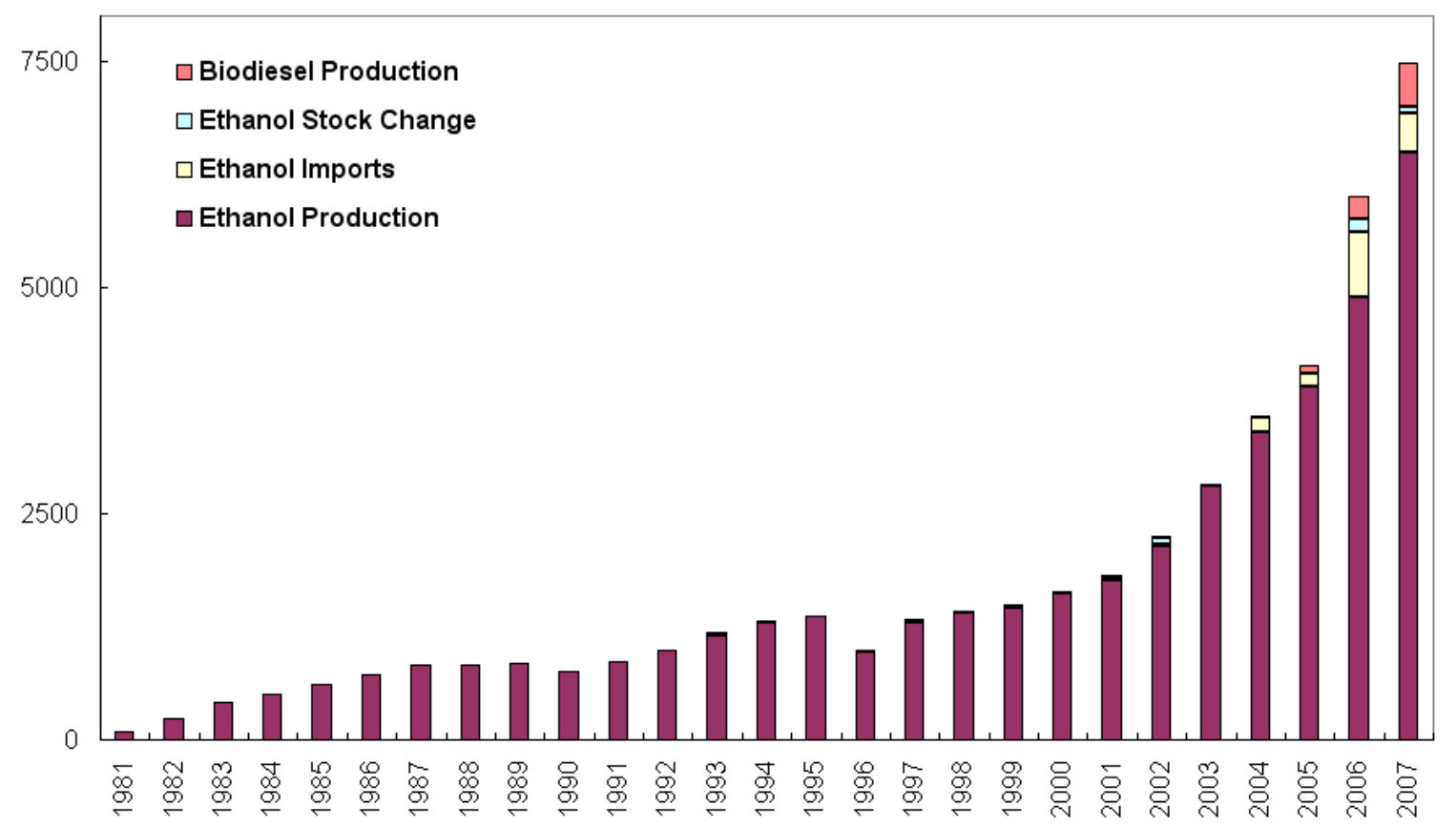

Sources: EIA. Annual Energy Review. Table 10.3: Fuel Ethanol and Biodiesel Overview, 1981-2007 
Figure 5 - United States Corn Production and Utilization, 2001-2008 Million bushels

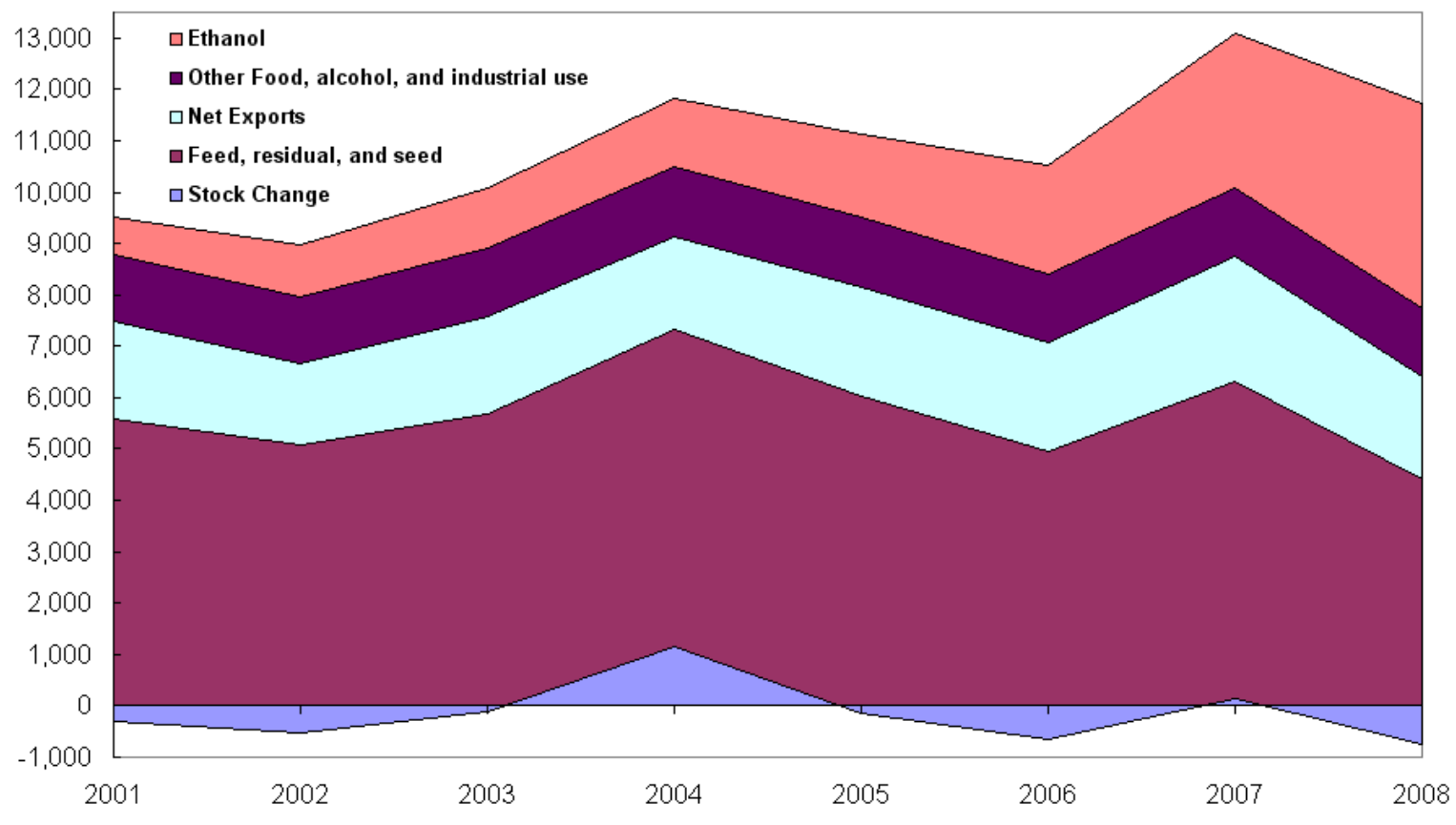

Source: ERS, USDA Feed Grains Database, Yearbook Tables.

\section{Figure 6 - World Ethanol Production, 2005-2017}

Millions of gallons

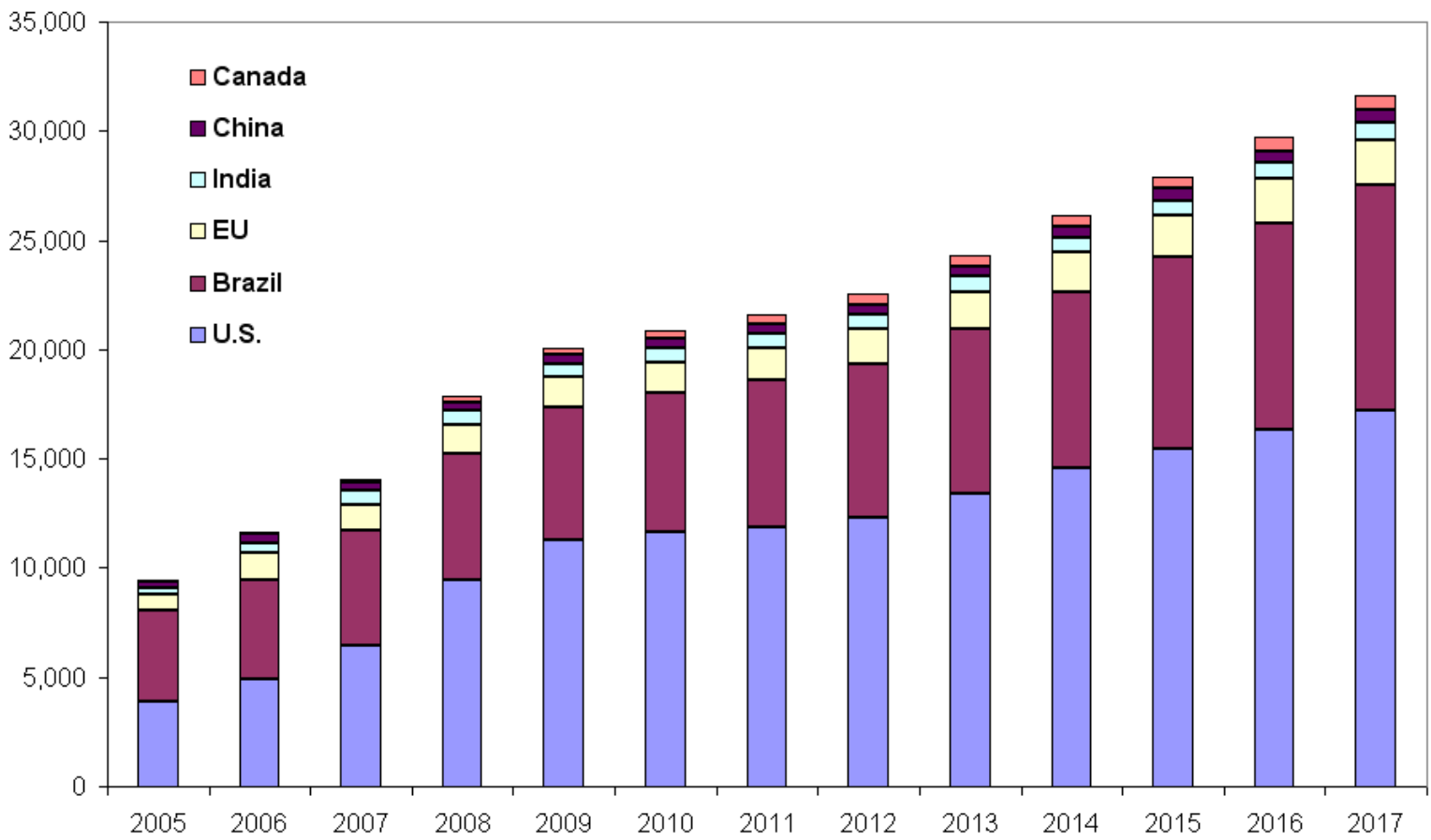

Source: FAPRI 2008 U.S. and World Agricultural Outlook. 
Figure 7 - World Biodiesel Production, 2005-2017

Millions of gallons

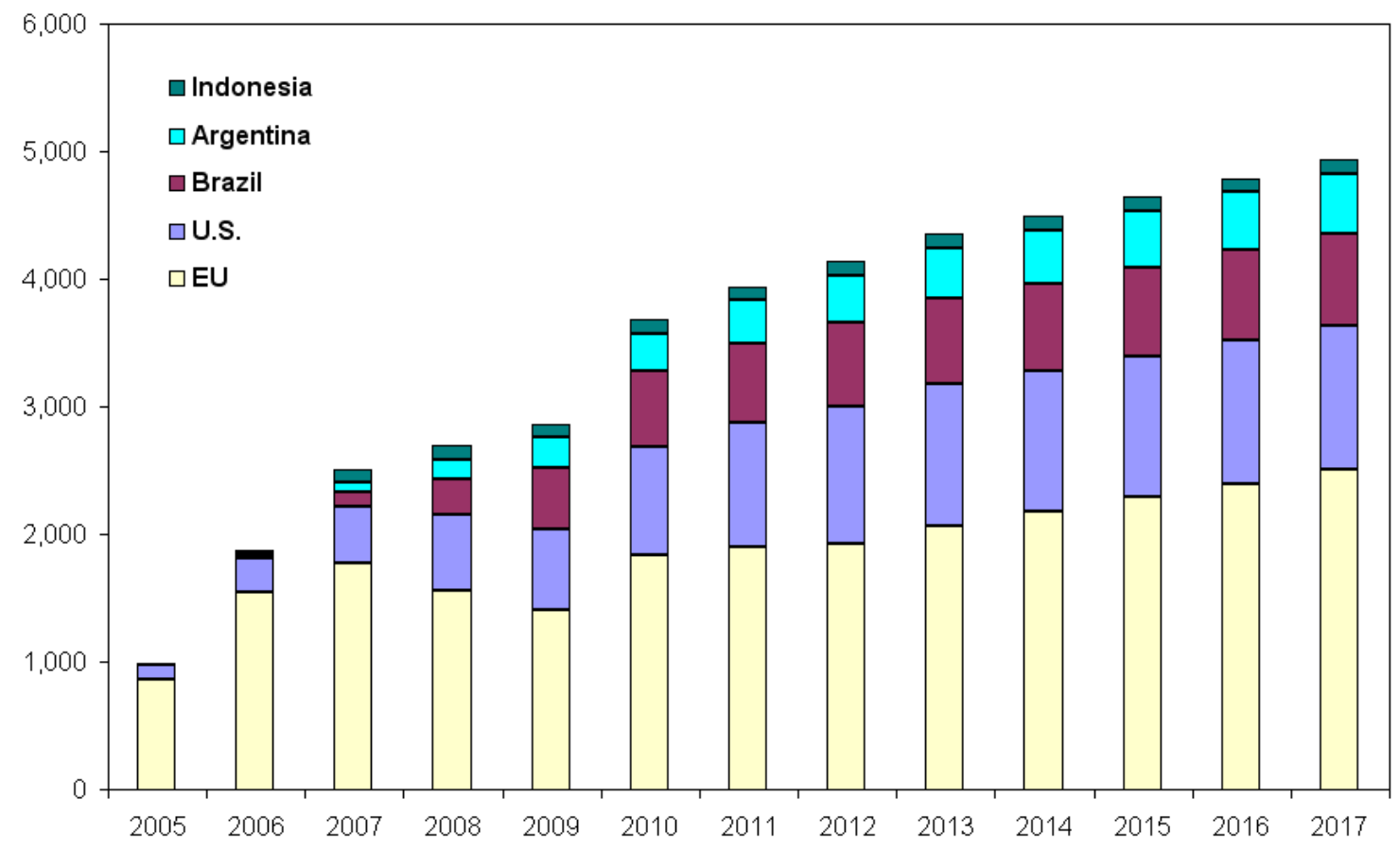

Source: FAPRI 2008 U.S. and World Agricultural Outlook. 